\title{
Ferramentas para boas práticas na propriedade leiteira
}

\author{
Julio Viégas, Pedro Urubatan Neto da Costa, Renato Zanella, Osmar D. Prestes
}

https://doi.org/10.4322/mp.978-65-991393-1-4.c5

\section{Introdução}

Produzir alimento acessível e de boa qualidade para fazer frente ao crescimento populacional é uma das grandes dificuldades mundiais, principalmente nos países em desenvolvimento. O leite é uma fonte importante de proteína de alto valor biológico, cálcio e outros minerais e de vitaminas A, B1 e B2. O leite, além dos inúmeros derivados, também participa da composição de vários alimentos presentes na dieta da população brasileira. No Brasil há falhas no controle de qualidade do leite, o qual precisa ser feito com muita atenção, uma vez que o leite é um produto altamente perecível, consumido por crianças e idosos.

Atualmente, a utilização de medicamentos veterinários e agrotóxicos em alguma etapa da produção agropecuária, como na produção e armazenamento de cereais, bem como para fins profiláticos com administração no gado leiteiro, é fato indiscutível. Entretanto, o uso inadequado dessas substâncias, seja pela não observância aos prazos de carência após a aplicação, às dosagens corretas e à via de administração recomendada, ou ainda pela terapia indiscriminada e uso de substâncias proibidas, pode deixar resíduos destes compostos em produtos alimentícios de origem animal e vegetal, colocando em risco a saúde humana.

Da mesma forma, a cadeia produtiva do leite no Rio Grande do Sul (RS), em seu aspecto da qualidade da matéria prima, tem passado por mudanças nos últimos anos, decorrentes das fraudes detectadas pela Operação Leite Compensado. O RS produz mais leite do que consome internamente, precisando exportar para outros estados, entretanto enfrentou problemas de mercado pela imagem negativa de algumas marcas. As fraudes resultaram em fechamento de indústrias sendo que algumas destas não pagaram os produtores pelo leite já coletado. Também houve extinção de rotas de coletas, determinando a exclusão ou desistência de produtores, geralmente os de menor escala de produção.

As autoridades responsáveis reagem com a criação da Lei Estadual do Leite (lei 14.835) promulgada pelo Governo Estadual em janeiro de 2016, que estabelece multas pesadas ao setor da indústria no caso de irregularidades na produção, transporte e comercialização do leite cru refrigerado. As novas exigências implicaram em maior investimento em tecnologia de análises laboratoriais bem como em logística, por parte da indústria, o que pode exigir uma escala maior de produção dos produtores, visando diluir os custos destes investimentos.

Várias empresas já adotam a coleta mínima de 100 litros por dia por produtor. Na região de Santa Maria (RS), a partir de julho de 2015, praticamente todas as empresas compradoras passaram a implantar programas de pagamento conforme a qualidade microbiológica e composição do leite, fazendo com que a Assistência Técnica ampliasse seu trabalho nesse tema. A Emater/RS-Ascar tem intensificado ações junto 
aos produtores assistidos, orientando sobre a ordenha higiênica entre outros aspectos ligados à qualidade.

A qualidade microbiológica do leite cru refrigerado é importante para o rendimento na industrialização e o tempo de permanência na prateleira (varejo), entre outros aspectos. Baixas Contagens de Células Somáticas (CCS) e Contagens Padrão em Placas (CPP) são alvos da indústria. Mas não são somente os aspectos ligados à industrialização que devemos considerar, é fundamental lançar um olhar também sobre a questão indireta da qualidade, por exemplo, altas CCS são um indicativo de que a vaca está deixando de produzir leite devido à ocorrência de mastites subclínicas (redução de até 30\%). A ordenha bem conduzida pode evitar infecções ou transmissões para os demais animais.

\section{Ordenha higiênica na propriedade - o que é importante discutir com os produtores}

A ordenha, a limpeza dos equipamentos, o resfriamento, tudo feito dentro dos padrões estabelecidos pela pesquisa evitam a perda da qualidade microbiológica do leite. A medida geral é evitar que sujidades, principalmente matéria orgânica, portadoras de bactérias, posam ir parar no resfriador. Para isso, é importante considerar inclusive aspectos antes da ordenha, como por exemplo, evitar que vacas muito sujas entrem na sala de ordenha. Quanto mais úberes e tetos muito sujos (provavelmente contaminados com bactérias) entrarem na sala de ordenha, maior será a probabilidade desta sujeira parar no leite do resfriador. Neste caso o piqueteamento com pastagens perenes de alta qualidade, formando um "tapete verde", tem contribuído muito na limpeza das vacas, pois a cada dia teremos uma "cama" nova e limpa para as vacas. A formação de lama é um desafio para os produtores. Rigo et al. (2016) relatam a alternativa implantada por uma família de produtores do município de Chiapeta - RS, construindo um corredor de 0,7 m de largura, de concreto armado, que leva os animais da sala de ordenha até as pastagens, o que acabou por determinar um diferencial importante na qualidade do leite produzido.

Outra estrutura importante é uma adequada sala de espera, bem calçada e coberta para que dê tempo de escorrer o excesso de água nos dias de chuva, antes de entrarem para a sala de ordenha. Na rotina de ordenha o produtor deve evitar excesso de água na limpeza dos tetos, aliás, se estiverem limpos o uso da água deve ser evitado. Ao molhar demasiadamente o úbere, e este é de difícil secagem, o excesso de água tende a ser sugado para as teteiras levando bactérias do exterior do úbere para o leite.

A rotina é simples: lavar os tetos somente se muito sujos; retirar os três primeiros jatos em caneca de fundo preto para verificar a presença de grumos; realizar o pré-dipping (pré-desinfecção) e enxugar os tetos com papel toalha para retirar excesso de bactericida; colocar as teteiras para ordenha e por último, o pós-dipping (pósdesinfecção) com selante. As vacas devem ficar em pé pelo menos 1 hora após a ordenha. O California Mastit Test (CMT), ou teste da raquete, deve ser realizado periodicamente em todas as vacas em lactação, para investigação de mastite subclínica. Quando for detectado grumos na caneca de fundo preto, ou se a avaliação no CMT foi positiva, o Médico Veterinário deverá ser consultado.

Conforme a Instrução Normativa $n^{\circ}$ 62, de 29 de Dezembro de 2011 entende-se por leite, sem outra especificação, o produto oriundo da ordenha completa e ininterrupta, em condições de higiene, de vacas sadias, bem alimentadas e descansadas. Daí se subentende que a extração do leite somente pode ocorrer em condições não estressantes ou desafiadoras ao sistema imune das vacas leiteiras. O processo de 
ordenha somente poderá ser eficiente, rápido e profundo se o animal identificar todo o processo como uma situação que atende o seu bem-estar. Ou seja, em vacas estressadas a tendência é que o patamar produtivo seja reduzido e a incidência de doenças, sobretudo as infecções das glândulas mamárias, aumente. A condução dos animais para a sala de ordenha deve ser realizada sempre pelas mesmas pessoas, as quais devem estar treinadas para este manejo. A sala de ordenha não deve ter fontes de estresse como: animais estranhos, barulhos que não da própria ordenhadeira, piso escorregadio, cantos vivos, pontos de descarga elétrica, etc. Todo o material necessário para a realização da ordenha deve estar disponível e higienizado antes de trazer os animais para a sala de espera. Importante, na sala de ordenha somente a ordenha pode se realizada, ou seja, manejos como inseminação, diagnóstico de gestação, exames diversos, vacinações, vermifugações, etc, não devem, nunca, ser realizados neste local, pois como os mesmos causam determinado nível de estresse, as vacas acabam por associar o mesmo ao ambiente.

A lavagem ou não dos tetos é uma decisão crucial no adequado manejo da ordenha, pois o excesso de água utilizado no preparo dos animais para a ordenha, além de ser um excelente veículo para o transporte de bactérias para o leite no resfriador (aumento da CPP), aumenta a probabilidade de novas infecções da glândula mamária. Desta forma, podemos afirmar que quanto menos água utilizarmos no início da ordenha melhor será a qualidade do leite obtido e melhor será a saúde do úbere. O produtor deverá sempre avaliar a necessidade da lavagem do teto, a partir do estabelecimento de um escore de sujidade dos mesmos. Escores com quatro níveis são propostos, sendo que os dois primeiros são condições aceitáveis de limpeza, para os quais não se recomenda o uso de água. Lembrando que para os escores três e quatro somente os tetos serão lavados, nunca o piso do úbere ou o próprio úbere. Importante salientar que, quando escores mais elevados de sujidade são identificados nos animais, as fontes desta sujidade devem ser identificadas e uma solução deve ser encontrada.

A etapa seguinte é a verificação de ocorrência de mastites clínicas por meio do uso da caneca de fundo preto e/ou telado. Realiza-se o teste da caneca retirando os primeiros três jatos de leite e verificando no contraste do leite com o fundo preto a ocorrência de alterações macroscópicas do leite, como grumos, coágulos, pus e sangue. Ao mesmo tempo o descarte dos três primeiros jatos contribui na redução da CPP em nível de tanque resfriador.

Após o teste da caneca de fundo preto deve ser realizada a pré-desinfecção de todos os tetos. Com esta prática pretende-se reduzir a ocorrência, sobretudo das mastites ambientais, que resultam normalmente em mastites clínicas. Importante salientar que o produto a ser utilizado é específico para a pré-desinfecção, pois é mais diluído que o utilizado na pós-desinfecção. A diluição pode ser feita na propriedade, seguindo a recomendação do fabricante. Aplicadores sem retorno do produto e que promovem a produção de espuma no copo aplicador são os mais recomendados, evitando o uso excessivo de desinfetante. Após a aplicação deve-se aguardar 30 segundos para realizar a secagem dos tetos. A secagem, considerando que ou a lavagem dos tetos ou a pré-desinfecção, ou ambos ocorreram, é etapa obrigatória e fundamental na obtenção de um leite de qualidade e na manutenção da saúde do úbere. Esta prática tem por objetivo retirar o excedente de produto aplicado no teto, evitando a contaminação do leite, bem como realizar um arraste mecânico de partículas mais grosseiras aderidas ao teto e que não foram extraídas pela lavagem do teto, ou porque a lavagem não foi realizada.

Imediatamente após, o conjunto de ordenha deve ser colocado no úbere verificado se as teteiras estão bem aderidas aos tetos, sem entradas de ar que diminuem a eficiência de extração do vácuo. Espera-se que a ordenha tenha ocorrido de forma 
profunda em até no máximo oito minutos. O conjunto de ordenha apresenta o peso necessário para que a mesma fique bem posicionada nos tetos, sendo desnecessário, e contraindicado, aplicar uma pressão sobre o conjunto com as mãos ao final da ordenha, prática tão comum entre os produtores. A pressão do vácuo do equipamento deve ser verificada rotineiramente e o ordenhador deve ter o cuidado para que as teteiras não permaneçam nos tetos depois do fluxo do leite ter cessado. Esta situação que podemos denominar de ordenha a seco, ou sobre-ordenha, provoca traumas no teto, podendo ocasionar, por exemplo, o prolapso do canal do teto e consequentemente o aumento dos casos de mastites, pela perda da camada de queratina do canal do teto. Para a retirada das teteiras é fundamental interromper a ação do vácuo no conjunto de ordenha.

Depois de realizada a ordenha todos os tetos devem passar pela pós-desinfecção. Neste caso o produto a ser utilizado é mais concentrado que aquele da prédesinfecção e, preferencialmente, devem ter algum composto emoliente para preservar a saúde do epitélio do teto e algum selante para obstruir o canal do teto. Produtos com cores vivas também são interessantes de serem utilizados para verificar não somente que todos os tetos foram desinfetados, mas que a cobertura do teto foi realizada de maneira completa. Outra tecnologia disponível no mercado são os produtos anti-gotejamento que determinam a redução no desperdício do produto. $O$ objetivo do pós-desinfecção é a redução dos casos de mastite subclínica, que representam um prejuízo importante à atividade, pela redução na produção leiteira e pelo descarte de animais com mastite crônica. Para a identificação da mastite subclínica do rebanho é importante que seja realizado o CMT, ou teste da raquete mensalmente, ou que amostras do leite sejam enviadas aos laboratórios credenciados para a análise da CCS.

Em propriedades que realizam a suplementação alimentar dos animais no cocho, esta deve ocorrer sempre após a ordenha, servindo como auxiliar no controle das mastites ambientais, pois assim forçamos que os animais não se deitem logo após a ordenha.

Certamente o Brasil teria um aumento vertiginoso da produção leiteira se implementasse um programa rígido de controle das mastites. Diferentes países, como por exemplo, os Estados Unidos, já estabeleceram anos atrás protocolos como o Programa dos Seis Pontos, a saber: i) correto manejo da ordenha (treinamento e conscientização da equipe de trabalho); ii) bom funcionamento da ordenhadeira (realizar revisões de forma rotineira); iii) desinfecção obrigatória dos tetos após a ordenha; iv) tratamento de todos os casos de mastite clínica, assim que identificados; v) descarte de vacas com mastite crônica; vi) instituição da Terapia da Vaca Seca, em todos os quartos mamários de vacas que entram no período seco.

Outras formas de condução da ordenha são possíveis, atingindo resultados semelhantes. Em alguns casos algumas das etapas acima mencionadas podem ser suprimidas, em outros, outros manejos podem ser instituídos. Entretanto, o fundamental é que a partir de um manejo de ordenha instituído e que dê resultados positivos no incremento da produção e redução das enfermidades do úbere, os protocolos devem ser estabelecidos rigorosamente. A equipe de trabalho deve ser exaustivamente treinada e deve, sobretudo, entender os motivos para a adoção de determinadas práticas. Por fim, estes protocolos, ou Boas Práticas de Produção devem estar impressos de maneira clara e objetiva e serem fixados em pontos estratégicos do ambiente da ordenha para que, em caso de dúvida, os membros da equipe possam consultar em qualquer momento. Somente com o comprometimento de toda equipe é que podemos obter um leite de altíssima qualidade para o consumidor final. 


\section{Determinação de resíduos e contaminantes em leite}

Apesar da evidente importância do leite para a economia do Estado do Rio Grande do Sul, um conjunto de problemas merece a atenção de toda Cadeia Produtiva tendo como objetivo o regramento sistêmico para uma melhoria da qualidade do setor. Aumentar a quantidade e melhorar a qualidade do leite produzido é o grande desafio imposto ao setor leiteiro gaúcho.

Como os medicamentos veterinários e agrotóxicos podem deixar resíduos tóxicos nos alimentos, os mesmos deverão atender às normas de qualidade e segurança não só para a saúde animal, mas especialmente para a saúde pública e o meio ambiente. A proteção do consumidor depende do correto uso desses produtos, evitando-se com isso riscos à saúde humana. No entanto, é preciso que esta problemática não seja encarada de modo simplista; é necessário que se entenda o alimento de origem animal presente na mesa do consumidor como ponto final de uma grande cadeia iniciada nas fazendas. A presença destes compostos no leite é prejudicial à saúde de quem o consome, podendo causar alergias ou resistências bacterianas aos antibióticos, dificultando o tratamento de doenças. O Ministério da Agricultura, Pecuária e Abastecimento pró́be, segundo a Normativa 62 de 2011, a comercialização de leite com resíduos de medicamentos acima dos limites permitidos. Cuidados que devem ser observados para evitar a existência de antibióticos no leite: somente aplique medicamentos nas vacas mediante receita veterinária; fique atento ao período de carência (prazo para eliminação do produto após a última aplicação); descarte todo o leite da vaca tratada pelo tempo determinado na carência; leia a bula e o rótulo do antibiótico e ordenhe os animais com aplicação de antibióticos por último (manejo).

Considerando o grande número de medicamentos veterinários e agrotóxicos disponíveis atualmente, é de fundamental importância a realização de análises amplas de resíduos de medicamentos veterinários e agrotóxicos para comprovar a qualidade do leite bovino consumido. Essas análises são realizadas empregando-se técnicas cromatográficas acopladas à espectrometria de massas (LC-MS/MS e GC-MS/MS) que estão disponíveis no Laboratório de Análises de Resíduos de Pesticidas (LARP) do Departamento de Química da Universidade Federal de Santa Maria (UFSM). O LARP-UFSM atua nesta área de análises há mais de 20 anos e é acreditado pelo CGCRE/INMETRO desde 2013. Atualmente, o LARP-UFSM tem a capacidade de analisar cerca de 200 agrotóxicos e 80 medicamentos veterinários em amostras de leite. Os resultados das análises permitem a identificação das falhas em termos de manejo sanitário, como a utilização de produtos não permitidos para gado leiteiro e a ocorrência de resíduos acima do valor máximo permitido. Assim, as análises viabilizam a tomada de medidas corretivas visando preservar a saúde dos consumidores e garantir a qualidade do leite em termos de resíduos e contaminantes.

\section{Conclusão}

Como pode ser verificado, a obtenção de um leite de qualidade é dependente de uma série de fatores, que devem ser avaliados e estudos em seus pormenores. É improvável que venhamos a obter um produto com alto rendimento na indústria e com longa vida de prateleira se todos os elos da cadeia produtiva não estiverem treinados, capacitados e cientes do papel fundamental que desempenham em nível da segurança alimentar.

As Boas Práticas de Produção devem obrigatoriamente ser instituídas naquelas propriedades que almejam aumentos no nível de produção, com protocolos bem definidos, claros e de simples entendimentos pelos funcionários e ou familiares 
envolvidos na atividade. Análises adequadas de resíduos de medicamentos veterinários e agrotóxicos permitem atestar a qualidade do leite bovino produzido em relação a estes contaminantes.

\section{Referências}

RIGO, D.S et al. A extensão rural e a construção do conhecimento em rede: A experiência da rede municipal de unidades de observação pedagógica (Rede Leite).

Chiapetta/RS. In: Anais... XI congresso da sociedade brasileira de sistema de produção, 2016. Pelotas, 6 a 8 de julho de 2016.

\section{Autores}

Julio Viégas ${ }^{1}$, Pedro Urubatan Neto da Costa $^{2}$, Renato Zanella ${ }^{3}$, Osmar D. Prestes ${ }^{4}$

1. Engenheiro Agrônomo e Doutor em Zootecnia pela UFRGS, Professor Titular do Departamento de Zootecnia da UFSM. Tem experiência em pecuária leiteira e produção de forragem conservada. E-mail: jviegas.ufsm@gmail.com

2. Engenheiro Agrônomo e Mestre em Extensão Rural pela UFSM. Extensionista rural nível superior da EMATER/RS-ASCAR. Tem experiência na área de Agronomia, com ênfase em extensão rural e gestão de sistemas de produção leiteira. E-mail: urubatan@emater.tche.br

3. Químico Industrial e Doutor em Química Analítica pela Dortmund Universität, Alemanha. Professor Titular do Departamento de Química da UFSM. Coordenador do Laboratório de Análises de Resíduos de Pesticidas (LARP). Pesquisador $1 \mathrm{C}$ do CNPq na área de resíduos e contaminantes em alimentos e amostras ambientais. E-mail: renato.zanella@ufsm.br

4. Químico Industrial e Doutor em Química Analítica pela UFSM. Professor Adjunto do Departamento de Química da UFSM, Gerente de Pesquisa do LARP-UFSM. Tem experiência na área de resíduos e contaminantes em alimentos e amostras ambientais. E-mail: osmar.prestes@ufsm.br 